GEOPHYSICAL RESEARCH PAPERS

NO. 39

\title{
THE CHEMISTRY AND VERTICAL DISTRIBUTION OF THE OXIDES OF NITROGEN \\ IN THE ATMOSPHERE
}

LEWIS E. MILLER

NOVRMeer 1954

\footnotetext{
GEOPHYSICS RESEARCH DIRECTORATE AIR FORCE CAMBRIDGE RESEARCH CENTER BEDFORD MASSACHUSETTS
} 